Article

\title{
A Collaborative Transformation beyond Coal and Cars? Co-Creation and Corporatism in the German Energy and Mobility Transitions
}

\author{
Jeremias Herberg * $\mathbb{C}^{\text {, }}$, Tobias Haas, Daniel Oppold and Dirk von Schneidemesser \\ Institute for Advanced Sustainability Studies (IASS) Potsdam, Berliner Straße 130, D-14467 Potsdam, Germany; \\ tobias.haas@iass-potsdam.de (T.H.); daniel.oppold@iass-potsdam.de (D.O.); \\ Dirk.vonSchneidemesser@iass-potsdam.de (D.v.S.) \\ * Correspondence: jeremias.herberg@iass-potsdam.de
}

Received: 23 March 2020; Accepted: 15 April 2020; Published: 17 April 2020

check for updates

\begin{abstract}
In this article, we critically discuss the role of collaboration in Germany's path towards a post-carbon economy. We consider civic movements and novel forms of collaboration as a potentially transformative challenger to the predominant approach of corporatist collaboration in the mobility and energy sectors. However, while trade unions and employer organizations provide a permanent and active arena for policy-oriented collaboration, civil society groups cannot rely on an equivalently institutionalized corridor to secure policy impact and public resonance. In that sense, conventional forms of collaboration tend to hinder the transformation towards a post-carbon economy. Collaboration in the German corporatist setting is thus, from a sustainability perspective, simultaneously a problem and a solution. We argue for more institutionalized corridors between civil society and state institutions. Co-creation, as we would like to call this methodical approach to collaborating, can be anchored within the environmental and industrial policy arenas.
\end{abstract}

Keywords: just transition; legitimacy; climate protest; industrial lobby; incremental change

\section{Introduction}

Some of the most pressing challenges facing the world undoubtedly result from carbon-intensive industries such as the coal or car industries. Transformations away from dependence on these industries require fundamental shifts in societal norms and values, combined with ambitious environmental policy decisions which need to be broadly legitimated in order to withstand populist undermining and socioecological conflict [1]. For industrial societies that have organized along democratic values, the legitimacy of such public decisions is crucially dependent on the opportunities for citizens to take part in the respective decision-making processes. Therefore, deeper collaboration between policy-makers and affected communities seems vital to increase both the viability and legitimacy of ambitious climate policies. Yet, does the affirmative notion of a collaborative transformation hold any weight, given the increasing conflicts in climate policy?

In this article, we critically discuss the role of collaboration in Germany's path towards a post-carbon economy. We consider civic movements and novel forms of collaboration as a potentially transformative challenger to the predominant approach of corporatist collaboration in the mobility and energy sectors. However, while collaborative approaches in civil society have been very prominent in relation to both the planned coal phase-out and urban reforms in mobility policy, these movements are limited in their policy impacts and resonance. Collaborative connections between the state and the affected civic communities are less robust than those in the corporatist arena, and struggle to compete in the institutionalized policy-making arena. While trade unions and employer organizations provide 
a permanent and active arena for policy-oriented collaboration [2], civil society groups cannot yet rely on an equivalently institutionalized corridor. In that sense, the conventional forms of collaboration between politics, trade unions, and industry are rooted in a carbon-based economy, and therefore hinder the radical transformations necessary for a post-carbon economy. If present forms of collaboration in the German corporatist system represent a problem, they are simultaneously, from a sustainability perspective, also a key aspect of the solution. How can collaboration beyond the corporatist system enhance an ambitious sustainability transformation?

In the first section, we depict the German landscape of collaboration with and against carbonintensive industries. The second section presents two case studies of Germany's coal phase-out and mobility transitions. The third section critically discusses the collaborative formats among civil society groups, and proposes democratic formats for them to better connect to workers and rural communities. Finally, we conclude with an outlook on further research and on lessons for other transformations and countries.

\subsection{Unpacking the Notion of Collaborative Transformation}

In political discourse the connection between collaboration and transformation is habitually claimed to be necessary and positive. One exemplary political field where affirmative notions of dialogue and mutual engagement gloss over inherent conflicts is climate policy. Even the most heated negotiations are often framed in the language of dialogue and collaboration [3-5]. International climate diplomacy in particular has used this affirmative language to create broad alliances, for instance when the Preamble to the Resolution on the Sustainable Development Goals adopted by the United Nations General Assembly pledged that "no one will be left behind" [6]. It has been sensible for practitioners to follow these semantics and to help improve collaborative processes. More recently, however, negotiations within the United Nations Framework Convention on Climate Change (UNFCCC) have led to pressure at the national and subnational levels, where the inherent contradictions of ambitious climate policy and industrial economies became increasingly graspable and subject to public controversy. After environmental activists had long used the notion of climate and environmental justice to highlight the losses and damages of the climate crisis, the concept of a Just Transition (JT) has been appropriated by labor unions and governments, predominantly in the Global North, to capture the uneven distribution of policy effects within industrial regions. It becomes increasingly clear that a transformation beyond fossil fuels can entail distributional injustices and cannot take place without institutional struggles between trade unions, environmental NGOs, businesses, and national and supranational organizations. More recently, even broader publics that transcend institutionalized arenas have taken center stage. The youth movement "Fridays for Future" is just one instance where the political talk of global collaboration has met fierce criticism due to the many conflicts that the policy-makers involved have ignored or failed to reconcile. The legitimacy of ambitious climate policy becomes increasingly contested, especially in countries of the Global North, because of an inherent hypocrisy between their stated international climate ambitions and their internal politics. Thus, while the affirmative language of collaborative transformations has a long legacy in climate policy, the implied cross-sectoral struggles become more and more visible.

Our case studies from Germany are selected against this backdrop of climate policy and sustainability discourse. On the one hand, as studies in environmental and technological policy have shown [7], German political culture tends towards collaborative and consensus-oriented processes. On the other hand, there are profound doubts about the genuine sincerity and ambition of recent advances in German environmental policy [8]. The federal government has played a moderately ambitious role in climate diplomacy, but has simultaneously maintained a carbon-based economy and the corresponding tripartite system between industry, trade unions, and politics and administration [2]. Thus, in sight of the hypocrisies of international climate policy, many challenges for a post-carbon transformation in Germany-especially those concerning energy and mobility—can be best illustrated through collaborative modes of politics. 
Using the case of Germany, the purpose of this article is to provide critical scrutiny of the connection between collaboration and the achievement of ambitious climate policies. Empirically, we use primary literature and research on both energy and mobility policies to trace how the competition for the social shaping of ecological transformations fundamentally impacts their achievability. In short, we trace the interaction between the "how" and the "what" of post-carbon transformations. More precisely, our research question is: How does the interaction between industrial and civic approaches to a collaborative transformation shape the legitimacy of an ambitious energy and mobility transition? Theoretically, we aim at an idealtypical understanding about how various collaborative constellations are shaping the legitimacy and transformational dynamic of German energy and mobility policy. A relational, power-sensitive, and temporal conception seems necessary to conceive of the role of contrasting logics of collaboration, and to understand their interrelated effects on the pace and outcome of recent decarbonization efforts. In terms of policy, our research question directly addresses recent developments in Germany. In a normative dimension, we provide a critical assessment of civic and corporatist forms of collaboration based on political-theoretical considerations. Going further, we pinpoint the transformational potential of a third approach, which has not yet impacted Realpolitik in Germany. This approach, for which we borrow the term "co-creation", can potentially leverage transformational shifts within the deadlocked constellation of the civic and corporatist arenas.

\subsection{Collaboration as an Institution in German Policy-Making}

The role of collaboration in German policy-making is best described as an institution: it represents, along different values and among various actors, "socially sanctioned, that is, collectively enforced expectation(s) with respect to the behavior of specific categories of actors or to the performance of certain activities" [9] (p. 10). As described below, even competing actors in the German climate policy arena do not object to the general value of collaboration. Yet, while this institution per se is not contested, there are competing interpretations among organizations, groups, and individuals. Depending on the place and social status of collective actors, their collaborative actions are directed at different goals and partners, and based on contrasting values. According to an institutional understanding of collaboration, such competing approaches do not inevitably lead to direct conflict. Institutions become more contested in times of disruption or crisis, however, and methods of justification and collaboration may correspondingly be used more pluralistically and creatively [10]. Based on this theoretical viewpoint, we can ask how the institution of collaboration-especially when renegotiated in times of crisis-affects the speed and achievability of ambitious climate policies. Empirically, we observe three approaches to collaboration, of which the third has not affected climate policy to date, but has recently emerged in sustainability discourse and democratic practice.

Firstly, carbon-intensive economies involve a close and often collaborative relationship between state institutions, industry representatives, and trade unions. Germany has a long tradition of this tripartite concertation of interests, but is one example of a consensus- or negotiation-oriented democracy with its corporatist tendency [11] (p. 188). Against this backdrop, which has at least accompanied and even strengthened the carbon-based economy of Germany, it would be naïve to assume that the notion of collaboration is necessarily emancipatory or transformative in the sense of a sustainability transformation. By contrast, in the course of the 1980s and 1990s, these corporatist alliances even begun to include, and thereby appropriate, environmental interests. Karl-Werner Brand even concludes, with regard to the social rules that govern environmental politics, that "[A]n alternative to the strategy of limited cooperation is no longer an option" [12] (p. 252). Those alliances involve bargaining between trade unions and industrialists, the installment of stakeholder commissions pertaining to questions of cross-sector policy-making, and, of course, informal communication between individual representatives. Corporatist methods of collaboration are so stable that they even shape the party-based democratic system, with the Social Democratic and Socialist parties being traditional partners of trade unions, and conservative and economic liberalists representing employer interests. Social policy and lower-skilled workers, as well as environmental agendas, have either lost or never gained the same level 
of institutionalized collaboration with state representatives [13]. One of the exemplary methods that have even shaped a broad acknowledgement of climate policy ambitions are stakeholder commissions. However, despite their declared aim of bringing all affected stakeholders to the table and identifying solutions based on a sensitive balance between all positions, these expert commissions are commonly criticized for only enforcing those positions that, arguably, already exist. Some authors point to their "fig leaf" function (implying the concealment of problematic issues), whereas others even argue that stakeholder commissions lead to the deinstitutionalization of governmental action [14] (p. 14).

Secondly, environmental policy arenas have been especially influenced by civic forms of collaboration. The ambition to introduce transformative policies with regard to energy, mobility, and other areas first developed in Germany through grassroots movements [12]. In the energy sector, citizen initiatives and environmental groups mobilized public protest long before the so-called energy transition was endorsed by the German Government [15]. These groups have traditionally opposed industrial interests and built close ties with emerging fields of environmental research [16], and have even helped to originate left-wing or green political parties, NGOs, and research institutes. Moreover, social movements are generally characterized by a certain inventiveness with regard to communication and collaboration [17]. Environmental movements have recently (re-)discovered creative means of building collaborative collectives [18], digital tools of communication [19,20], and public disobedience [21,22]. Very different civil society movements and newly formed parties such as Podemos in Spain, the Degrowth community, or, most famously, the protest groups that emerged after the financial crisis in 2009, endorse new principles and methods of collaboration and communication. Yet, these movements have been criticized as consisting of predominantly well-educated, young, and cosmopolitan individuals [23]. For example, the "Fridays for Future" student movement disproportionately attracts participants from well-educated families [24] (p. 10). Thus, as a consequence of such structural bias, the creative and often emotionally costly principles of collaboration can be perceived as being inaccessible to large sections of society. In the face of these critiques, it is important not to generalize from these idiosyncratic and place-specific movements to a larger population.

Thirdly, there is an emerging discourse around the terminology of co-creation. To date, this discourse has certainly had very little impact on German environmental policy-making. Yet, we observe a trend within the sustainability literature and in democratic practice. In sustainability studies, the term "co-creation" is used to discuss methodical forms of collaboration between scholars, policy-makers, and civic groups that aim to achieve transformational change [25,26]. Co-creation often arises in a corporate and managerial context, denoting the collaborative creation of economic value $[27,28]$. In a more democratic vein, we observe communities of group facilitation and public participation that use the term to describe heterogeneous forms of collaboration that take place when public administrators invite citizens to collaboratively shape policy [29]. One practical application is the concept of so-called "mini-publics" [30]. "Mini-publics" are randomly selected samples of citizens who are tasked with, for example, identifying "recommendations" for action to tackle so-called "wicked problems". "Mini-publics" are powerful procedural vehicles for increasing and accelerating "throughput legitimacy" in decision-making processes concerning complex issues. The work of such a randomly selected group of citizens takes place within the framework of a process design that ensures beforehand that it can build on pre-existing knowledge and argumentations concerning the issue at hand. The non-partisan, non-professional background of these randomly selected citizens has repeatedly proven to be a powerful asset in overcoming some of the systemic shortcomings of the institutions and procedures of tripartite consensus building [31,32]. It opens up the possibility of identifying pathways for action beyond any consensus that could otherwise be achieved via bargaining and negotiation among a given topic's most powerful or longest-established actors. The most prominent operationalization of the "mini-public" logic is certainly to be seen in so-called "Citizens' Assemblies" as employed at the national level in Ireland and Canada [33,34]. These cases illustrate the capabilities of ordinary citizens to contribute to collective decision-making processes on a national 
scale in order to overcome deadlock and insufficiencies in more established procedures for collective decision-making. In Ireland, the process logic of the Citizens' Assembly has, among other issues, paved the way for referenda on same-sex marriage and progressive legislation on abortion. In the German context, the increasing acceptance of co-creative approaches can also be seen in a hackathon that the Federal government has recently organized in order to find digital solutions in times of the the Covid-19 pandemic.

It remains unclear how these three collaborative constellations affect transformational change in environmental policy. The first two approaches, in particular, are in a highly dynamic interaction when it comes to recent environmental policy. We hypothesize that both logics are simultaneously being applied to the question of post-carbon industries, and compete for influence over policy decisions while endorsing very different understandings of what a legitimate transformation would look like. Hence, while climate policy on the international stage engages in a largely affirmative discourse on collaboration, the national arena is divided among different fields of collaboration [35]. The role of co-creation is even more ambiguous, as it has not yet affected Realpolitik in Germany. Given the very visible presence of the civic and corporatist arenas, and given the emerging co-creation discourse within the sustainability literature, it is worthwhile to first investigate the empirical process of collaboration in energy and mobility policy. Second, as co-creative practices may soon become part of this constellation, it is important to discuss potential effects in the constellation of civic and corporatist actors. In order to conceptualize and analyze this dynamic, we need a concept of collaboration as well as an interconnected concept of change.

\subsection{Concepts of Legitimacy, Collaboration, and Incremental Change}

From the perspective of theory-building, the purpose of this article is to provide an idealtypical understanding of the interplay between collaborative constellations and transformational change. The following paragraphs introduce three basic concepts that, based on the empirical case studies, will then be combined in section three.

The first concept is legitimacy. From a political-theoretical viewpoint, any robust change is related to the communicative process of legitimation [36]. Only when many groups assign plausibility and credibility to novel institutions, powerful actors, or singular policies can change persist within democratic societies. In times of relative stability, as was well illustrated during recent decades in Germany, the political order is largely unquestioned. In times of crisis, however, when the normative validity of a political order may increasingly be questioned or challenged, legitimacy becomes a bone of contention [37] (p. 77). Antagonist groups compete over the social rules that circumscribe the legitimate process of decision-making and collaboration. It becomes clear that the questions of change and legitimacy are intricately related. Moreover, they relate to processes of negotiation and collaboration. International collaboration, for instance, has enjoyed increasing legitimacy, giving rise to arenas of global governance affecting change or stability in climate policy and other fields [38].

The second concept is derived from a field of study that has contributed to further structure this dynamic, namely social movement theory. The opposition between incumbents and challengers has proven a valuable concept [39-41]. That is, a policy field is predominantly shaped by the actors or coalitions that impose their understanding of a good policy process and their social rules on decision-making and collaboration. Those dominant actors can be defined as incumbents. Incumbents may be confronted by challengers, i.e., other groups that, to date, have been less able to establish their concepts or regulatory ideas. Those challenger groups seek strategic opportunities to counter the dominant order and weaken the respective alliances among incumbents. Previous studies have highlighted how dominant coalitions between state, industry, and labor organizations have managed to sustain fossil-based industries and have absorbed the challenges made by environmental groups and parties [8,40]. It is important to understand that these mesolevel approaches do not translate the idea of face-to-face interaction into broader societal change, thus assuming a direct "face-off" between opposing and internally homogeneous groups, respectively. Rather, incumbents and challenger groups 
can themselves be divided within their ranks, and may co-exist for decades before their antagonistic relationship actually solidifies within a social conflict [42]. In times of greater stability, their relationship can switch in miniscule but meaningful ways, for instance when one party successfully advances within the silent conflict, such as by shaping a law or gaining public attention through media coverage.

As a third concept, we need a concept of change through conflict and competition. That is, we seek to account for both the struggles between proponents and opponents, and the kind of change that can occur when various arenas of collaboration co-exist. This addresses a blind spot in sustainability studies primarily addressing large-scale changes. While there have been many proposals concerning "grand transformations" [43-46] and multilevel transitions [47,48] within the sustainability literature, there has been little distinction made between the more incremental kinds of change that are much more likely to occur in consensus-oriented polities such as Germany. Other concepts rightly emphasize the importance of conflict and discussion [49,50], but rarely elaborate on the co-existence and interdependence of diverse arenas of conflicts and collaborations [39,51,52]. Consequently, we cannot rely on an integrated concept of collaborative transformation, but instead turn to a third, singular concept of change that can be combined with the incumbent-challenger distinction. Streeck and Thelen have proposed a more fine-grained distinction to appreciate several forms of incremental but transformational change [9].

1. Displacement occurs "not through explicit revision or amendment of existing arrangements, but rather through shifts in the relative salience of different institutional arrangements within a 'field' or 'system'."

2. Layering "involves active sponsorship of amendments, additions, or revisions to an existing set of institutions."

3. Drift entails that "the world surrounding an institution evolves in ways that alter its scope, meaning, and function."

4. Conversion describes that "(t)he redirection of institutional resources that we associate with conversion may occur through political contestation over what functions and purposes an existing institution should serve".

5. Exhaustion is a form of change "in which behaviors invoked or allowed under existing rules operate to undermine these."

These five forms of change can occur intentionally, but also unintentionally, when industrial interest groups and civic movements push their respective agendas while rarely being in direct conflict, let alone engaging in any form of negotiation. For instance, environmental movements may successfully displace a more dominant idea, may change its surrounding, or may undermine a given set of rules by re-appropriation. We thus propose a combination of concepts to capture the transformational dynamic of competitive collaboration. The concept of challengers and incumbents is helpful to capture "the how", while "the what" in our understanding can be conceptualized by a multifaceted understanding of incremental change. The interplay between legitimacy, collaboration, and change remains an empirical puzzle. One exemplary field of study is that of climate policy and, more specifically, the energy and mobility transitions in Germany.

\section{Case Studies: Germany without Coal and Cars?}

\subsection{First Case: Mobility Transition}

In Germany, the transport sector is a major source of greenhouse gas emissions as well as more localized pollutants. While other sectors, notably energy, have made significant progress on reducing emissions, the transport sector has been responsible for rising emissions in recent years. Analogous to the "Energy Transition", the call for a "Mobility Transition" has become loud in recent years, and is now, more than ever, front and center of German political debate and agendas, especially in cities. The costs of the current and former orientation toward motorized individual transport (MIT) powered by fossil fuels have long been identified. Accordingly, there have been calls from across the political spectrum 
for policies to address this issue. However, these calls have not resulted in transformational policy that has shifted the mobility paradigm in a significant way. More automobiles are now being registered, and they also tend to be larger, heavier, and more energy intensive [53]. In the national budget for 2019, the German Government increased investment in rail transport by $4 \%$, while increasing the budget for highways by $45 \%$, and Germany remains in the bottom quarter of western European countries in terms of per capita investment in rail transport [54]. Despite identifying these problems, political decisions in the transport sector cause emissions to continue to rise [55].

This political stagnation has roots in the German political economy. Mobility politics in Germany is subordinated to the field of economic policy. Despite the fact that the budget of the Traffic Ministry is the third largest of any federal ministry, transport infrastructure is handled as something that results from, and is necessary for, economic growth [56]. In this way, economic policy dominates transport policy.

While the funding structures for transport infrastructure cut across governmental tiers, they do not really allow significant alternatives for political decision-makers at any level. "Hard infrastructure" (as opposed to mobility services or mobility as a service) is funded by the Federal Traffic Ministry. Although state governments are responsible for distributing federal funds and raising their own funds for transport projects, the funding structures guarantee the Federal Traffic Ministry a leading function; consequently, innovations in mobility have not featured in the agenda-setting function of the federal ministry's funding activities [57]. The Federal Traffic Ministry often declines funding for certain types of proposals: not only for mobility innovations (e.g., services), but also for financing "hard" transport infrastructure other than automobile infrastructure. This is illustrated by the case of Berlin, where a center-left political constellation attempted to shift federal funding from a highway project to build bicycle lanes. The federal ministry blocked the use of funds for anything other than constructing a city highway project. The message was: either build the highway or return the funds to the federal ministry, the funds were not allowed to be used for constructing bicycle paths [56]. This example points to a boundary in the political field: the structural narrowing of the decision spectrum, through funding mechanisms of regional and local political actors, disincentivizes anything other than hard infrastructure for the automobile.

Similar examples have led most political parties to pursue an automobile-oriented mobility politics that lacks alternatives. Across all governmental tiers, mobility politics that depart significantly from the automobile-oriented status quo are lost against the prioritization of economic concerns, largely due to the importance of Germany's domestic automobile industry to the economy [58]. A parliamentary inquiry into meetings between top ministerial politicians and representatives of mobility-related organizations revealed a significant preference for representatives of the automobile industry over other industrial or civil groups. All seven of Chancellor Merkel's meetings, and all 11 of Traffic Minister Dobrindt's meetings recorded during the timeframe in question (between 2015 and 2017) were with representatives of the automobile industry, but none with environmental, civil, or other transport representatives [59]. This aligns with previous findings, that concerns over economic sustainability are foregrounded in mobility policy reform processes due to the influence of the automobile industry lobby [60].

The automobile industry makes up an important part of the economy and is a major factor in the comfortable economic position that Germany has obtained. This has a long history, aptly described by Lijphart [61] as "interest group corporatism". The close and long-established relationship between politics, the automobile industry, and labor unions has led to firmly rooted prioritization of the automobile industry's interests in German politics [56,58]. Employees in the automotive industry are mainly represented by the trade union IG Metall (German Metalworkers' Union), which in turn bases a considerable part of its organizational power on this sector. This corporatist constellation has enabled something of a stable balance between social and business interests, but has not offered politics a partner for pursuing political options that give greater priority to environmental concerns. 
The financial crisis of 2008-2009 reduced the buying power of Germans both in the domestic and export markets, and could have been taken as an opportunity to reform policies away from the production and use of private cars. Similarly, the diesel emissions scandal that began in 2015 might have marked a turning point in domestic mobility politics. However, the solid rooting of the automobile industry and associated labor unions in the corporatist constellation enabled both the automobile industry and political spheres to weather recent storms that in other contexts might have served as a window of opportunity to set new priorities and begin a mobility transition in earnest. Thus, despite the broad public broad acknowledgement of both the climate crisis [62] and the causal role of the motorized transport paradigm, the mobility transition has long been prevented.

This scenario sees powerful actors pitted in opposition to a "just transition", i.e., against changes that are in the public good. In the case of mobility, that would mean increasing potential mobility while at the same time causing fewer negative traffic-related externalities. The hope for a mobility transformation then lies with civil society pushing politics to react, the motivation for which-namely enabling and even initiating policy change toward a just transition-is already a legitimizing factor in and of itself. In addition, there is also a growing willingness within IG Metall to deal with the future of mobility beyond the fixation on the private automobile. For example, IG Metall is calling for a transformational part-time work bonus to enable employees to gain further qualifications in activities beyond automobile production [63]. Nonetheless, a mobility transition will require lasting and durable legitimacy, perhaps in an even stronger way than the energy transition, and is likely to only yield incremental change. This is also because mobility is an obtrusive issue [64]: unlike elements of an energy transition, in which individuals may not be aware of whether their electricity is generated from coal, solar, or nuclear power, citizens will certainly be aware of the differences in utilizing a bicycle or public transport as opposed to a private car. A mobility transformation cannot be conducted in the background; consequently, even small changes will require broad legitimacy.

Achieving a mobility transition in this context, then, means new constellations of actors, alongside which new collaborative formats must evolve. The following examples illustrate the emergence of such collaborations in the movement toward a mobility transition in Germany:

- There are movements for bicycle referendums in approximately 30 cities throughout Germany, the first of which was in Berlin and provided the input and legitimacy for a new mobility law. This was then formally legitimized when passed by Berlin's state parliament in 2018 [65]. Citizens in numerous German cities and federal states have followed this model, accompanying their demands and proposals with continued campaigns entailing various degrees of direct collaboration with politics.

- Movements for car-reduced or car-free neighborhoods are not new in Germany. This can be observed in examples like Freiburg's Vauban sustainable urban district, which in 2001 already pioneered a car-reduced neighborhood model. More recently, initiatives such as "Verkehrsberuhigter Samariterkiez" (Traffic-calmed Samariter Neighborhood) and "Autofreier Wrangelkiez" (Car-Free Wrangel Neighborhood) have sprouted up in Berlin, pursuing car-reduced and car-free living concepts from the bottom up. In Hamburg, "Ottensen Macht Platz" (Ottensen Makes Room) is a project in which citizens have produced plans for achieving change in their immediate vicinity, and initiated collaboration with local government to work towards their implementation. Thus, with ideas and expectations coming from citizens, expectations for the resulting policies in the form of changed infrastructure have been demanded and endowed with legitimacy.

- Tangible mobility concepts are also responsible for new forms of collaboration with politics and civil society. The "Radbahn Berlin" project, developed by a civil society group to utilize space beneath an elevated city-center train line throughout three city districts, has prompted a further example of collaboration between citizens and government [66]. The initiators are currently collaborating with government at the municipal, state, and federal levels, and have received a federal grant of more than two million euros (some of which goes directly to their governmental 
partners at the municipal level) to implement their proposal along a test section of the route. Again, legitimacy derives from civil actors producing an idea which at various moments is acknowledged by the elected government through certain outcomes, such as a funding grant or an invitation to pursue the project collaboratively.

- In the city of Wuppertal, a citizens' group collaborated with the city government for more than ten years to realize a 20-kilometer pedestrian and bicycle path along the Nordbahntrasse, a former railway alignment. Not only was the group largely responsible for the initial concept, and for establishing it on the political agenda, they were also involved in organizing its funding, and even assumed responsibility for constructing parts of the project and involving the community in maintaining the route after its completion. The completed greenway has provided a safe option for active transport, as it links major parts of the city. This has led to an increase in active transport, particularly cycling [67].

These four examples can be traced back to initiatives by citizens and/or civil society, which provided a civic collaboration partner for local or state governments outside of the traditional corporatist constellation. In each case, these led to the establishment of new social configurations: the iterative process of government and civil society working together to generate material responses to the interest constellations rooted in civil society. This places the two actors (government and civil society) in a complex collaborative mode of engagement with one another, where both have interests in a good-quality and timely result, but define those parameters differently. Business interests may or may not be included in this collaborative constellation; the important difference from corporatist collaboration is the decoupling of these actors from their roots in the economy.

These civically oriented collaborative constellations result from citizens assuming agency in mobility politics. Such a shift is notable, since in Germany this field has traditionally been dominated by professionals, experts, and technocratic influences [58,68,69], resulting in significant barriers to the integration of citizen and civil society knowledge. However, the civically oriented collaborative mode is now enabling steps that go beyond the deeply rooted, automobile-oriented power structure that has hindered Germany's ability to realize a mobility transition, and includes the opening of policy arenas to experts not rooted in corporatist interest groups. Change, in Thelen and Streek's [9] sense of "conversion", thus reinterprets the rules governing who is an expert.

The civic mode of collaboration aligns the interests of civil society and government. Governmental actors are feeling the pressure from the reinvigorated climate movement associated with "Fridays for Future" and other civil society initiatives. However, these often stop short of mapping out a plan for achieving their demands. We certainly do not wish to imply that it is illegitimate for civil society to criticize without providing answers. Rather, we highlight the fact that certain civically rooted initiatives actively propose potential pathways that would not necessarily be open to political actors alone, thereby enabling an alternative to the more limited spectrum of solutions possible within corporatist collaboration. Embedded in the old formations of interest group corporatism, political actors require new partners to successfully depart from entrenched positions. Designing climate policies in a collaborative mode potentially offers pathways for these new constellations to become effective. In addition, this could induce trade unions to break away somewhat from their traditional corporatist orientation and open themselves up to a turnaround in mobility, which could also significantly improve the quality of life of their members beyond their mere status as wage workers [70].

As a whole, numerous civically rooted initiatives in the mobility sector are geared toward transformational change by way of displacement and conversion [9]. As regards displacement, the dominance of the institution of the automobile in the city is being eroded. Although these efforts are generally small-scale, local, and decentralized, they nonetheless represent significant potential for fulfilling the necessary role of the partner for governmental actors in a sustainability transformation, not least because much mobility policy is the purview of local actors. The rising salience of mobility concepts that reject automobile-centeredness opens a political space for pursuing alternatives. Paired with this displacement, conversion is becoming evident in certain political fields at 
all levels of government. In this way, the demands of civil society employ the changing salience of the role of the car in society to redirect the attention, and thus the resources, of federal and municipal transportation departments away from the automobile and toward sustainable alternatives. It must be emphasized, however, that these transformations remain emergent at present, and that full-scale mobility transformations remain uncertain.

\subsection{Second Case: Coal Phase-Out}

The German "Energiewende" (energy transition) is a protracted process that has its roots in the anti-nuclear movement of the 1970s. This movement challenged the existing energy regime and its supporting forces. The perceived "Atomic State" (Der Atomstaat) [71] became a particular target of criticism. This included not only the state but also nuclear corporations and parts of the trade unions that supported the German nuclear program. Programmatic for the movement was the 1980 text "Energiewende. Wachstum und Wohlstand ohne Erdöl und Uran" ("Energy Transition. Growth and Prosperity without Oil and Uranium") [72], which outlined alternative development pathways to that of the fossil-nuclear energy regime. Incremental change accelerated in the late 1990s. In 2001, the first nuclear phase-out decision was negotiated under a Red-Green coalition government (comprising the Social Democratic Party and Alliance '90/The Greens). A year earlier, the German Parliament had passed the Renewable Energy Sources Act (EEG), which laid the foundation for a relatively rapid expansion of renewable energy sources in the electricity sector. By 2019, renewable energies accounted for more than $40 \%$ of Germany's electricity supply, and the use of nuclear energy will end in 2022. Against this backdrop, disputes in recent years have shifted in the direction of coal. This was mainly due to the "Ende Gelände" alliance, which regularly engages in campaigns of civil disobedience to paralyze or even shut down coal infrastructure in mining areas. In addition, the conflicts surrounding coal culminated in autumn 2018, when the North Rhine-Westphalia state government initiated clearance of the remaining part of the ancient Hambach Forest, which has been successively consumed by opencast mining in the Rhineland district for more than 40 years. As early as 2013, treehouses were constructed and occupied in the Hambach Forest to prevent its continued destruction by the expansion of surface coal quarrying [73].

Coal is an important pillar of the German political economy and is facing a fundamental transition over the next two decades [74]. In the coalition agreement of 2018, the federal government stipulated a massive expansion of renewable energies (targeting a 65\% share of electricity generation in 2030). An energy system based largely on renewable energies is not only possible, but can also be achieved at relatively low system costs. An expected increase in carbon prices should make Germany's low-grade lignite coal, which is particularly harmful to the climate, increasingly economically unattractive. Germany can also be fully supplied without using coal to generate electricity if the targets for expanding renewable energies are met. Furthermore, Germany is part of an integrated European electricity grid, so that possible short-term undersupply would not threaten energy security. At the same time, regulations can be introduced to reduce oversupply with renewable energies. The electricity price increases that are anticipated if coal is phased out by 2038 are likely to remain within reasonable limits (approximately 0.1-0.2 euro cents/kWh) [75].

However, in the energy industry, too, opposing notions of collaboration co-exist and have become increasingly antagonist. On the corporatist side is the dominant alliance of energy companies and trade unions, together with state institutions and political parties. This alliance has navigated the coal industry throughout regional crises in eastern Germany and has even endured the German energy transition. Workers in the coal industry are mainly organized through the IG BCE (Industrial Union in the Mining, Chemical and Energy Industry), and, to some extent, in the services trade union ver.di. The IG BCE in particular has a strong pro-coal policy, and the fronts between environmental activists and the labor union are often hardened. Famously, Germany phased out nuclear energy due to safety concerns in the wake of the Fukushima accident of 2011, but also in response to long-standing public opposition. In contrast, the coal phase-out, which would clearly have broader environmental 
impacts, has only recently emerged as a legitimate policy question. The most prominent arena in which the dominant alliance has collaboratively negotiated a vision for phase-out was the recently concluded "Commission on Growth, Structural Change, and Employment" (henceforth referred to as the "Coal Commission"). Aside from the actors mentioned from the corporatist spectrum of employer organizations and trade unions, commission members also included environmental NGOs as well as climate and social policy scientists. Following tough negotiations, the commission members agreed on the following key points (with only Hannelore Wodtke, representing the citizens' initiatives in Lusatia, voting against) overnight from 25 to 26 January 2019:

- By the end of 2038, the coal phase-out should have been completed (by 2035, if possible). Coal-fired power plant capacity of 12.5 gigawatts (GW) is to be taken off-grid by 2022 (coal-based capacity is presently $42.6 \mathrm{GW})$.

- Further interim targets have also been defined, but these remain relatively vague. Compensation for rising electricity prices is also planned.

- The affected federal states are to receive structural change aid amounting to 40 billion euros over the next 20 years.

In addition, power plant operators were promised compensation payments, an adjustment allowance for affected employees aged 58 and over was proposed, and the preservation of the Hambach Forest was declared "desirable".

In this respect, despite its reported disorganization, the commission succeeded in developing a compromise proposal involving almost all parties, including far-reaching proposals for the design of the coal phase-out. However, in view of the agreement reached in January 2020 between the federal and state governments to implement the compromise, political rifts are again widening. All of the commission members on the environmental spectrum published an open letter clearly criticizing the plan and pointing out that it would fail to implement key points of the compromise. This indicates that several conflicts remain unresolved: it is unclear whether the corporatist tendency in the German model can be permanently balanced in the relationship between politics, economy, and sustainability with environmental agendas. Examples include whether even more villages will yet be evacuated for opencast mining excavations or how the distribution of the structural transformation aid and the level of compensation for power plant operators will be structured, based on the advocacy of trade unions or employer organizations. Lastly, the Coal Commission's recommendations to the federal government, which are yet to be implemented through a parliamentary process, have met with fierce criticism as they are insufficient to meet internationally negotiated climate policy goals.

Aside from disagreement over the "what", opposition groups and local movements have also endorsed very different approaches to collaboration over recent decades. It is important to note in this context that they have dealt with a myriad of issues including village displacement, air quality, demographic change, and even violent conflict and oppression. Some of the most prominent approaches over the last few years include:

- One characteristic of the German energy transition is that it has long had a strongly decentralized character. New energy cooperatives, municipal utilities, farmers, or private individuals have contributed to the democratization of energy supply. The "Bündnis Bürgerenergie" ("Citizens' Energy Alliance") was founded in 2014 in response to growing attacks on the system of guaranteed feed-in tariffs that was fundamental to Germany's Renewable Energy Sources Act (EEG). This alliance focuses on stronger networking among the various actors (citizen financiers, energy producers, co-owners, etc.) that have forged a decentralized and democratized renewable energy system in many parts of Germany; organizes an annual civic energy convention; and also lobbies for the democratic and co-creative transformation of the energy system.

- Since 2015, the Ende Gelände alliance has regularly organized campaigns of civil disobedience. The alliance is strongly inspired in its forms of action by the anti-nuclear movement, and has managed to position coal energy at the center of public attention and establish new forms of 
cooperation through broad networking with other, less radical actors as well as local people from Hambach Forest. The resulting pressure became so great that the German Government decided, within the framework of the coalition negotiations in 2018, to settle the issue by establishing the above mentioned Coal Commission [71,76].

- In recent years, the Hambach Forest has become a symbol of resistance to coal-fired power plants, directed against the state's coal policy, the operating company RWE, and the IGBCE trade union. The latter has repeatedly spoken out against a coal withdrawal and, despite various dialogue formats, has a rather conflictual relationship with those activists occupying treehouses in the Hambach Forest. Nevertheless, the activists are supported by large sections of the local population. In this respect, actions concerned with the future of the forest have brought about new alliances that stand for a different, less domineering and environmentally destructive form of energy production.

- The "Grüne Liga" (Green League) was founded in 1990 out of the East German environmental movement, which was predominantly supported by the Church. It currently comprises four state associations, among others in Brandenburg and Saxony. Grüne Liga has long campaigned against the expansion of coal mining in the Lusatia region, and is well networked with civil society alliances in the other German lignite regions. Against the background of the heated political debate in Lusatia, Grüne Liga plays an important role in resistance to lignite extraction and in shaping sustainable structural change in the Lusatian mining areas.

The four examples outlined above suggest that the transformation of energy systems and the withdrawal of coal as an essential component of the transformation process will not take place without major changes in the social form of environmental politics. In addition to strong polarization and antagonistic starting positions between the environmental movement and the carriers of the fossil-nuclear energy regime, collaborative processes may be able to establish new forms of collaboration to counterbalance the established practices of corporatist arrangements, and set impulses for incremental change towards a more sustainable and democratic electricity supply. However, recent conflicts over the coal phase-out indicate that this will remain a contested issue. It remains to be seen to what extent trade unions such as the IG BCE and ver.di will also deviate from their pro-coal course and open up to alliances with the environmental movement.

\section{Analysis: Democratic Pitfalls of Corporatist and Civic Collaboration}

Both case studies show that the "how" of transitioning towards a post-carbon economy is broadly challenged in Germany, while the desirability of mitigating climate change remains relatively unchallenged $[2,77]$. Aside from a new right-wing populist movement and the AfD Party, whose climate-denialist lobbying has so far failed to influence environmental policy in Germany, both social movements and political interest groups compete to shape current climate policies. Against this discursive legitimacy of climate change policy, conservative and reactionary groups have tackled decision-making processes based on competing understandings of collaboration. Hence, the tactics of slowing or hastening the post-carbon transformation determine the dynamics of policy-making. Yet, against the backdrop of corporatist dominance, it is unlikely that the challengers can instill more than incremental changes. There is a hard-fought struggle to gain the political legitimacy that is necessary even for these incremental changes. How to grasp this struggle conceptually?

The concept of legitimacy established by Fritz Scharpf in the 1970s helps distinguish between a "government by the people" (i.e., reflecting citizens' concerns and preferences resulting from participation) versus a "government for the people" (i.e., the effective promotion of the common good) [78]. That is, there are struggles within society to influence policy or to benefit from it. In a more normative view, this means that a democratic process allows most of the affected citizens to be involved in both the input and output phases of a given policy, which would in turn increase the legitimacy of corresponding state actors. The role of corporatist and civic forms of collaboration in shaping a democratic transformation can be assessed against this background. As we argue in the following 
section, they both shape the legitimation process from opposite ends. However, it is unclear at present whether the trade unions and environmental movements will be able to cooperate more closely in the future and thus resolve hardened lines of conflict such as "jobs versus the environment" [79,80].

With regard to "output legitimacy", the corporatist collaborative constellations as they exist in Germany limit the achievability of ambitious climate policy. The deeply rooted and well-practiced mode of corporatist decision-making in Germany falls short of producing sufficient outcomes in the energy and mobility transitions, because the participating actors anchor their definition of the "common good", which guides final decisions, in the carbon-based economy. This becomes clear in mobility policy, for example the German Government's national budget increases for rail transport are routinely outstripped by those for highways, predictably leading to increasing road traffic emissions [53]. This can be attributed to "interest group corporatism" driven by the automobile industry, but also to funding mechanisms that disincentivize anything other than hard infrastructure for the automobile [56]. Furthermore, in the political process of phasing out coal, there are broadly visible deficits in the achievement of environmentally sufficient and socially just results. This is largely due to the broad but conflictual structure of the Coal Commission, such that its final recommendations were inadequate to meet Germany's internationally negotiated climate ambitions. Several major issues remain rather unclear, including population displacement and excavation of villages, the distribution of structural transformation aid, and the level of compensation for power plant operators. As a result of diplomatic challenges in the commission, they are largely left to the power-play between environmentalists, trade unions, and employer organizations. In short, to use Scharpf's classic concept, the corporatist form of collaboration is geared towards controlling the "output legitimacy" of current energy and mobility policies. This collaborative form of control impedes the socio-ecological changes that a broad public platform is calling for.

With regard to "input legitimacy", too little voice is given to the communities affected by both climate change and climate change policy, so that the legitimacy of political decisions is increasingly challenged, as illustrated by very different movements, such as the yellow vests in France or the "Fridays for Future" climate movement. Consequently, the externalities that human economic activity imposes on society and the environment are omitted from the equation, following a form of organizational and procedural blindness. It becomes apparent in the mobility transition that grassroots movements seek to take charge of traffic regulations in their immediate surroundings, collaboratively challenging local politicians and transport planners to take more ambitious steps. In the case of the coal phase-out, the grassroots level tends to be more oppositional rather than proactive. But in this case too, there is a growing amount of civil collaboration, when, for instance, local activists and local government officials form alliances against the displacement of villages. It is fair to say that these civic movements seek to control for the "input legitimacy" of climate policies, and are increasingly putting pressure on government in this process.

Although social movements push for ambitious climate policies, they also face inherent limits with regard to disrupting the corporatist tradition. These limits are spatial, material, and social in nature. One limiting feature is that the described initiatives are quintessentially local. The localized nature of their engagement often relies on the citizens' expertise as residents of their cities. Scaling up can therefore present challenges, and will require firm commitment, also in a financial sense, from the federal government if a mobility transition is to be successful. Moreover, civic engagement requires significant resources from citizens, thereby presenting barriers, since not all citizens have equal access to time, expertise, and social capital. Employer interests and trade unions are highly professionalized, whereas citizen groups cannot rely on similarly robust capacities. The successes of civil initiatives are thus linked to the educational and financial resources of the individuals involved. Individuals worried about making ends meet for themselves or their families would likely be unable to allocate the cognitive resources for such an initiative, even if the temporal resources were available. Given these limits—although the mentioned initiatives found a way to impact the policy arena-the group of 
participants admissible to the political arena was only slightly shifted away from the conventional corporatist alliance.

These aspects delimit the capacity of social movements to mobilize a level of "input legitimacy" that can actually influence the output of a sustainability transformation beyond the control of corporatist interests. On the one hand, the impact on, or scalability to, national policy-making; the social inclusiveness among activists; and the democratic representation of civil interests are regular weak points of most social movements. On the other hand, the described activist groups critically push for ambitious climate policy, and do so by democratic means such as public protest and civil disobedience. We can conclude that social movements play a significant but limited role in pushing for more ambitious agendas.

We end with a very mixed conclusion about the capacity of collaboration to instill transformational change, namely that the increasing challenges to "input legitimacy" are unlikely to suffice if the "output legitimacy" of post-carbon policies remains largely in the hands of corporatist alliances. Much more likely is a certain polarization, given the unbroken control over economic policy by corporatist alliances on the one hand and the rising popularity of climate activism on the other. What do we propose to overcome a potential deadlock situation?

\section{Proposal: Co-Creation Can Leverage Shifts in Environmental Policy}

A third concept of legitimacy, which captures the "how" of policy processes, is the notion of "throughput legitimacy". According to Vivien Schmidt, this highlights the "efficacy, accountability and transparency of [ ... ] governance processes along with their inclusiveness and openness to consultation with the people" [81] (p. 1). We argue that an increase in throughput legitimacy can help to overcome the increasingly deadlocked camps of corporatist and civic collaboration. This, of course, is not a normatively neutral position. Rather, against the backdrop of the increasing need to counter the climate crisis, we claim that substantially increased and improved collaboration between state actors and civil society can offer an alternative pathway to current corporatist tactics of decelerating climate policy. Moreover, this civic form of collaboration may support the democratic legitimacy of climate policy decisions and build institutions, so that state/democratic actors can rely on collaborative corridors to citizen groups.

This proposal can be integrated in the analysis as depicted in Figure 1. Providing corridors between civic and corporatist collaboration, our proposal points to institutionalized processes that need to be established and through which civic interests can impact climate policy decisions more directly than can be achieved by parliamentary representation. In our understanding, this process of building a corridor for society-policy collaboration can be seen in the co-creation discourse introduced above. In contrast to a more consumerist understanding of co-creation [82], this political understanding entails that deliberations among "normal" citizens who do not represent any organized interest are, under certain circumstances, able to provide highly valuable insights into possible and desirable options for action with regard to an issue at hand. Collaborative processes that manage to include a broader range of voices, ideas, and facts than those of the established corporatist actors are pivotal for achieving the types of broadly acceptable policy shifts that are imperative for steering societal transformations. In the midst of a corporatist reinforcement of carbon industries, however, the civic influence on sustainability politics must be institutionally anchored within the environmental and industrial policy arenas. This influence can, by means of the necessary political will to support co-creative formats, become a reliable and robust alternative to the quick and routine connections between industry, trade unions, and the state. While co-creation seems beneficial from a democratic perspective, does it also help to shape ambitious sustainability transformations? Using Streeck and Thelen's concept of incremental change, we propose five transformational effects of co-creation [9]:

- First, co-creation can contribute to the "displacement" of corporatist collaboration by shifting the focus towards civic constituencies. Mini-publics-particularly in the form of citizens' councils-offer possibilities for establishing arenas in which policy-makers can seek advice 
or find support for civic agendas that may be not be congruent with, find support for, or have the creative opportunity to be developed in constellations with strong industry and union input. For this to occur, it is advisable to shape co-creative processes in a way that they can capture the attention of diverse fractions of society, and create transparency as regards the procedural rules of the policy-making process itself. This transparency is a precondition to enable people to identify with the participating mini-public and to build or question their own convictions with regard to the issue(s) at hand.

- Second, co-creation can be a strategy of "layering" because it adds another formation on top of pre-existing citizen groups, but can also be added to more traditional forms of stakeholder consultation. Expert commissions, for instance, can be complemented by randomly selected citizens or civic organizations that have an option to provide alternative perspectives that can qualify or contextualize the advice from those expert commissions. For this to occur, however, it is advisable to shape co-creative processes in ways that consider the systemic imbalance of pre-existing knowledge and experience among randomly selected citizens compared with that of experts and professionals. Besides providing access to all relevant knowledge and facts, a mini-public needs to be effectively guarded as a safe space for open deliberation among its members. Otherwise, such a council can easily become prone to instrumentalization and manipulation. In cases where a mini-public is asked to deliberate on controversial topics, this type of process can also include hearings for representatives of the conflicting positions, enabling them to present their arguments directly to the mini-public.

- Third, co-creation can contribute to "drift" by changing the conditions under which corporatist forms of collaboration operate. For instance, institutionalized forms of civic collaboration, such as hackathons involving participants from various backgrounds, can pick up on the advice of expert commissions and create policy proposals that push for an independent reading of the results. For this to occur, it is advisable to shape co-creative processes in ways that facilitate the emergence of mutual trust among the different actors involved, which can most likely be achieved by designing processes over longer periods of time and with a sufficient focus on group dynamics and repeated opportunities to gain insights into one another's positions.

- Fourth, co-creation can foster a kind of "conversion" by integrating expertise that is free to embrace or reject to an ambitious transformation, while at the same time considering and prioritizing the needs of affected civic communities. For this to occur it is advisable to shape co-creative processes in a manner that enables civic perspectives to be incorporated sufficiently early to allow their values to be integrated into tangible future visions.

- Finally, co-creation can facilitate a form of change by encouraging a broad variety of actors to articulate local coping strategies to an interested and politically relevant audience. For this to occur, it is advisable to shape co-creative processes in a way that recognizes the principle of subsidiarity whenever possible. This means that in many circumstances it is preferable to work with several local mini-publics attached to local decision-making, rather than a single group at a higher level of governance. In this way, local contexts can be respected and adequately integrated into solutions.

If the aforementioned pitfalls are recognized in the design of a collaborative process, these approaches serve as a backbone to support democratic sustainability transformations while counterbalancing the corporatist representation of interests. This allows for drastically differing positions, opinions, and conceptions of "the problem" and "the solution(s)" to come into being in a political arena that is brought into existence solely for the sake of identifying and co-creating possible strategies for action. 


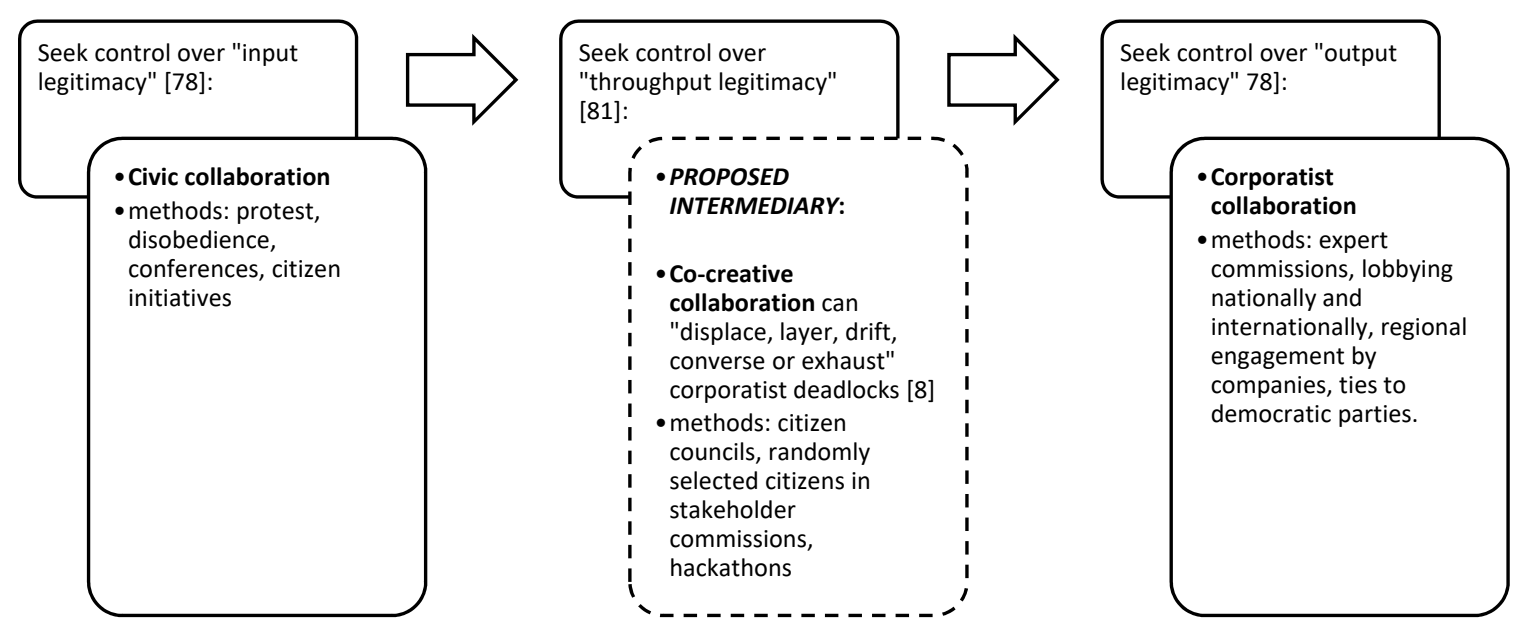

Figure 1. Co-creation as an intermediary in the legitimation of mobility and energy policy.

\section{Co-Creation in Just Transition Processes}

Given the persistent consensus on climate change, it is not so much the "what" but more the "how" that defines the struggle and pace of sustainability transformations in Germany. However, collaboration is both a civic and corporatist value, and thus represents an implicit bone of contention within the German climate policy discourse. With the rise of new industrial transition movements in the energy and mobility sectors, both understandings currently interact and, to differing degrees, define the rather incremental corridor for legitimate policy-making. Given the robust corporatist imprint on current climate policy, it is unlikely that civic pressure alone can counterbalance employer and trade union interests.

Yet, we have pointed out how civically oriented forms of co-creation may introduce incremental but transformational shifts. Against the backdrop of the predominant fields of collaboration-the arenas of corporatist climate policy and social movements-we argue for more institutionalized corridors between civil society and state institutions. Co-creation, as we call this methodical approach to collaboration, can transform the pressure coming from environmentally motivated citizens and collective actors into a reliable and robust alternative to the quick and routine connections between industry, trade unions, and the state. Along these lines, co-creation is a triple response that can: open the policy arena throughout a structured dialogue with the rising environmental movements, facilitate this dialogue so that it remains accessible for non-activists in the affected communities or industries, and present countervailing viewpoints to the exclusive corridors of corporatist lobbying. This re-distribution of political attention may contribute to a broader political discourse and even to decisions that address injustices among and between the communities that benefit or suffer from ambitious climate policies. If policy-makers fail to implement collaborative arenas that go beyond the corporatist and activist arenas, the broadly shared value of collaboration and the legitimacy of climate policy may be dismantled in a process of political polarization.

Future research should address the paradoxes of co-creation in relation to just transition processes: certainly, the relevance of co-creative pathways is increasing with the anticipated intensification of global climate change. When expectations among actors are increasingly in conflict, only reflexive understanding and collective practice can help to push sustainability ambitions. At the same time, however, the viability and practicability of co-creative pathways is continuously decreasing. With each failure to appropriately address the social and ecological dimensions of the climate crisis, the bar for co-creating dialogue is raised. Any transformational policy therefore needs to also lower the communicative threshold between communities that gain or lose from climate change and climate policies. Facilitators and institution-builders need to create arenas that facilitate three processes simultaneously: the articulation of ambitious responses to anticipated crises, the clarification of mutual 
expectations, and the nurturing of experiences of self-efficacy. How to meet this triple challenge remains one of the biggest puzzles for transdisciplinary sustainability research.

It is important to note the limitations of our study. This paper only provides a conceptual connection between the two transition processes in mobility and energy, suggesting that civic collaboration can offer an alternative or supplementary constellation to corporatist collaboration (without necessarily replacing it). We have not dealt with the material differences and sociospatial specificities of the car or coal industries, nor of corresponding social movements. Moreover, we could not elaborate on the role of trade unions in particular. We can only briefly point out that, at present, the most crucial strategy for a collaborative pathway out of the carbon industries might be the involvement of trade unions in civically oriented collaborations. While they have been involved in the tripartite model, international umbrella organizations such as the International Labour Organization, and also worker communities, are beginning to open up to environmental concerns [83]. A similar tendency in the national arena may tip the balance between corporatist sceptics and civic proponents of ambitious climate policy.

Author Contributions: This contribution constitutes the joint work of all authors under the lead of J.H. Conceptualization, J.H. and D.v.S.; methodology, J.H.; formal analysis, J.H., T.H., D.O. and D.v.S.; investigation D.v.S. and T.H.; writing — original draft preparation, J.H. and D.v.S.; writing—review and editing, J.H.; visualization, J.H.; project administration, J.H.; funding acquisition, J.H. All authors have read and agreed to the published version of the manuscript.

Funding: The research presented in this paper is partly funded by the German Federal Ministry of Education and Research (funding no. 03SF0561).

Acknowledgments: We would like to thank our colleagues in the projects "Social Transformation in Lusatia" and "Co-creation and Contemporary Policy Advice" at IASS Potsdam. Special thanks go to Dave Morris for his excellent editing services, and Annelie Gütte for her ever patient assistance.

Conflicts of Interest: The authors declare no conflicts of interest.

\section{References}

1. Kemp, R.; van Lente, H. The dual challenge of sustainability transitions. Environ. Innov. Soc. Transit. 2011, 1, 121-124. [CrossRef]

2. Hatch, M.T. The politics of global warming in Germany. Environ. Politics 1995, 4, 415-440. [CrossRef]

3. Schmieg, G.; Meyer, E.; Schrickel, I.; Herberg, J.; Caniglia, G.; Vilsmaier, U.; Laubichler, M.; Hörl, E.; Lang, D. Modeling normativity in sustainability: A comparison of the sustainable development goals, the Paris agreement, and the papal encyclical. Sustain. Sci. 2018, 13, 785-796. [CrossRef] [PubMed]

4. Keohane, R.O.; Victor, D.G. Cooperation and discord in global climate policy. Nat. Clim. Chang. 2016, 6, 570. [CrossRef]

5. Helgenberger, S.; Jänicke, M. Mobilizing the co-benefits of Climate Change Mitigation. IASS Working Paper, 2017. Retrieved on 2 December 2019. Available online: http://publications.iass-potsdam.de/pubman/item/ escidoc:2348917:6/component/escidoc:2666888/IASS_Working_Paper_2348917.pdf (accessed on 2 April 2020).

6. Weber, H. Politics of 'leaving no one behind': Contesting the 2030 Sustainable Development Goals agenda. Globalizations 2017, 14, 399-414. [CrossRef]

7. Jasanoff, S. Product, Process, or Programme: Three cultures and the regulation of biotechnology. In Resistance to New Technology; Bauer, M., Ed.; Cambridge University Press: Cambridge, UK, 1995; pp. 311-331.

8. Blühdorn, I. "Myths of Empowerment and Ecologisation. On the Rematerialisation of post-materialist Politics." ECPR, Joint Sessions, Copenhagen: 14-19. Retrieved at 2 December 2019. Available online: https: //ecpr.eu/Filestore/PaperProposal/e51d15b9-5df7-4f96-9b47-7af85091dfd0.pdf (accessed on 2 April 2020).

9. Streeck, W.; Thelen, K. Introduction: Institutional change in advanced political economies. In Beyond Continuity: Institutional Change in Advanced Political Economies; Streeck, W., Thelen, K., Eds.; Oxford University Press: Oxford, UK, 2005; pp. 1-39.

10. Battilana, J.; Dorado, S. Building sustainable hybrid organizations: The case of commercial microfinance organizations. Acad. Manag. J. 2010, 53, 1419-1440. [CrossRef]

11. Offe, C. Erneute Lektüre: Die» Strukturprobleme «nach 33 Jahren. In Claus Offe, Strukturprobleme des kapitalistischen Staates: Aufsätze zur Politischen Soziologie, Veränderte Neuausgabe; Borcher, J., Lessenich, S., Eds.; Campus: Frankfurt/Main, Germany, 2006; pp. 181-196. 
12. Brand, K.W. Transformationen der Ökologiebewegung. In Neue Soziale Bewegungen; Ansgar Klein, A., Legrand, H.-J., Leif, T., Eds.; VS Verlag für Sozialwissenschaften: Wiesbaden, Germany, 1999; pp. 237-256.

13. Raphael, L. Jenseits von Kohle und Stahl: Eine Gesellschaftsgeschichte Westeuropas nach dem Boom; Suhrkamp Verlag: Frankfurt/Main, Germany, 2019.

14. Offe, C. Einleitung: Reformbedarf und Reformoptionen der Demokratie. In Demokratisierung der Demokratie: Diagnosen und Reformvorschläge; Offe, C., Ed.; Campus: Frankfurt/Main, Germany, 2003; pp. 9-23.

15. Toke, D. Ecological modernisation, social movements and renewable energy. Environ. Politics 2011, 20, 60-77. [CrossRef]

16. Aykut, S.C. Energy futures from the social market economy to the Energiewende: The politicization of West German energy debates, 1950-1990. In The Struggle for the Long-Term in Transnational Science and Politics; Andersson, J., Rindzeviciute, E., Eds.; Routledge: Abingdon, UK, 2015; pp. 63-91.

17. Della Porta, D.; Mattoni, A. Social movements. Int. Encycl. Political Commun. 2016, 1-8. [CrossRef]

18. Fischer, F. Climate Crisis and the Democratic Prospect: Participatory Governance in Sustainable Communities; Oxford University Press: Oxford, UK, 2017.

19. Hopke, J.E. Hashtagging politics: Transnational anti-fracking movement Twitter practices. Soc. Media Soc. 2015, 1, 1-12. [CrossRef]

20. Zandbergen, D. "We are sensemakers": The (anti-) politics of smart city co-creation. Public Cult. 2017, 29, 539-562. [CrossRef]

21. Von Essen, E. Environmental disobedience and the dialogic dimensions of dissent. Democratization 2017, 24, 305-324. [CrossRef]

22. Dow, J.M. Environmental civil disobedience. In The Palgrave Handbook of Philosophy and Public Policy; Boonin, D., Ed.; Palgrave Macmillan: London, UK, 2018.

23. Olcese, C.; Saunders, C.; Tzavidis, N. In the streets with a degree: How political generations, educational attainment and student status affect engagement in protest politics. Int. Sociol. 2014, 29, 525-545. [CrossRef]

24. Wahlström, M.; Kocyba, P.; De Vydt, M.; de Moor, J. Fridays for Future: A New Generation of Climate Activism. IProtest for a Future: Composition, Mobilization and Motives of the Participants in Fridays For Future Climate Protests on 15 March 2019 in 13 European Cities. pp. 6-18. Available online: eprints. keele.ac.uk/6571/7/20190709_Protest\%20for\%20a\%20future_GCS\%20Descriptive\%20Report.pdf (accessed on 2 April 2020).

25. Mauser, W.; Klepper, G.; Rice, M.; Schmalzbauer, B.S.; Hackmann, H.; Leemans, R.; Moore, H. Transdisciplinary global change research: The co-creation of knowledge for sustainability. Curr. Opin. Environ. Sustain. 2013, 5, 420-431. [CrossRef]

26. Trencher, G.; Yarime, M.; McCormick, K.B.; Doll, C.N.; Kraines, S.B. Beyond the third mission: Exploring the emerging university function of co-creation for sustainability. Sci. Public Policy 2013, 41, 151-179. [CrossRef]

27. Aquilani, B.; Silvestri, C.; Ioppolo, G.; Ruggieri, A. The challenging transition to bio-economies: Towards a new framework integrating corporate sustainability and value co-creation. J. Clean. Prod. 2018, 172, 4001-4009. [CrossRef]

28. Lacoste, S. Sustainable value co-creation in business networks. Ind. Mark. Manag. 2016, 52, 151-162. [CrossRef]

29. Brandsen, T.; Verschuere, B. Co-Production and Co-Creation Engaging Citizens in Public Services; Routledge: New York, NY, USA, 2018.

30. Goodin, R.E.; Dryzek, J.S. Deliberative impacts: The macro-political uptake of mini-publics. Politics Soc. 2006, 34, 219-244. [CrossRef]

31. Sintomer, Y. From Deliberative to Radical Democracy? Sortition and Politics in the 21th Century. Legislature by Lot. An Alternative Design for Deliberative Governance; Verso: London, UK; New York, NY, USA, 2018.

32. Smith, G.; Wales, C. Citizens' juries and deliberative democracy. In Democracy as Public Deliberation; d'Entreves, M., Ed.; Routledge: Oxfordshire, UK, 2018; pp. 157-177.

33. Farrell, D.M.; O'Malley, E.; Suiter, J. Deliberative democracy in action Irish-style: The 2011 We The Citizens Pilot Citizens' Assembly. Ir. Political Stud. 2013, 28, 99-113. [CrossRef]

34. Warren, M.E.; Pearse, H. Designing Deliberative Democracy: The British Columbia Citizens' Assembly; Cambridge University Press: Cambridge, UK, 2008.

35. Hess, D.J. Sustainability transitions: A political coalition perspective. Res. Policy 2014, 43, 278-283. [CrossRef] 
36. Hurrelmann, A.; Schneider, S.; Steffek, J. (Eds.) Legitimacy in An Age of Global Politics; Palgrave Macmillan: London, UK, 2007.

37. Lipset, S.M. Political Man. The Social Bases of Politics; Heinemann: London, UK; Melbourne: Toronto, ON, Canada, 1960.

38. Zürn, M. Global governance and legitimacy problems. Gov. Oppos. 2004, 39, 260-287. [CrossRef]

39. McAdam, D.; Tarrow, S.; Tilly, C. Dynamics of Contention; Cambridge University Press: Cambridge, UK; New York, NY, USA, 2001.

40. Hess, D.J. Incumbent-led transitions and civil society: Autonomous vehicle policy and consumer organizations in the United States. Technol. Forecast. Soc. Chang. 2019, 151, 119825. [CrossRef]

41. Kungl, G. Stewards or sticklers for change? Incumbent energy providers and the politics of the German energy transition. Energy Res. Soc. Sci. 2015, 8, 12-23. [CrossRef]

42. Fligstein, N.; McAdam, D. A Theory of Fields; Oxford University Press: Oxford, UK, 2012.

43. Brand, U. "Transformation" as a new critical orthodoxy: The strategic use of the term "Transformation" does not prevent multiple crises. Gaia-Ecol. Perspect. Sci. Soc. 2016, 25, 23-27. [CrossRef]

44. Gürtler, K.; Rivera, M. New departures-Or a spanner in the works? Exploring narratives of impact-driven sustainability research. Sustainability 2019, 11, 6506. [CrossRef]

45. Hölscher, K.; Wittmayer, J.M.; Loorbach, D. Transition versus transformation: What's the difference? Environ. Innov. Soc. Transit. 2018, 27, 1-3. [CrossRef]

46. WBGU. World in Transition. A Social Contract for Sustainability; German Advisory Council on Global Change (WBGU): Berlin, Germany, 2011. Available online: www.wbgu.de/fileadmin/templates/dateien/ veroeffentlichungen/hauptgutachten/jg2011/wbgu_jg2011_en.pdf (accessed on 2 April 2020).

47. Geels, F.W. Socio-technical transitions to sustainability: A review of criticisms and elaborations of the Multi-Level Perspective. Curr. Opin. Environ. Sustain. 2019, 39, 187-201. [CrossRef]

48. Smith, A.; Voß, J.P.; Grin, J. Innovation studies and sustainability transitions: The allure of the multi-level perspective and its challenges. Res. Policy 2010, 39, 435-448. [CrossRef]

49. Haas, T. Struggles in European Union energy politics: A gramscian perspective on power in energy transitions. Energy Res. Soc. Sci. 2019, 48, 66-74. [CrossRef]

50. Jørgensen, U. Mapping and navigating transitions: The multi-level perspective compared with arenas of development. Res. Policy 2012, 41, 996-1010. [CrossRef]

51. Sovacool, B.K.; Hess, D.J. Ordering theories: Typologies and conceptual frameworks for sociotechnical change. Soc. Stud. Sci. 2017, 47, 703-750. [CrossRef] [PubMed]

52. Doganova, L.; Laurent, B. Keeping things different: Coexistence within European markets for cleantech and biofuels. J. Cult. Econ. 2016, 9, 141-156. [CrossRef]

53. DIW. Deutsches Institut für Wirtschaftsforschung: Verkehr in Zahlen 2014/2015; BMVI: Berlin, Germany, 2014.

54. Allianz Pro Schiene. Deutschland investiert zu wenig in die Schieninfrastruktur; Berlin, Germany, 2017. Available online: https://www.allianz-pro-schiene.de/themen/infrastruktur/investitionen/ (accessed on 9 March 2020).

55. Köder, L.; Burger, A. Umweltschädliche Subventionen in Deutschland, Aktualisierte Ausgabe 2016; Umweltbundesamt: Dessau-Roßlau, Germany, 2016.

56. Schwedes, O. Verkehr im Kapitalismus; Westfälisches Dampfboot: Münster, Germany, 2017.

57. Schwedes, O.; Ruhrort, L. Länderverkehrspolitik. In Die Politik der Bundesländer. Staatstätigkeit im Vergleich, 2nd ed.; Hildebrandt, A., Wolf, F., Eds.; Springer: Wiesbaden, Germany, 2008; pp. 235-256.

58. Schwedes, O. The field of transport policy. An initial approach. Ger. Policy Stud. 2011, 7, 7-41.

59. Bundestag, D. Kontakte der Bundesregierung zur Automobilindustrie; Antwort der Bundesregierung auf die Kleine Anfrage der Abgeordneten Herbert Behrens, Caren Lay, Eva Bulling-Schröter, weiterer Abgeordneter und der Fraktion DIE LINKE. 18. Wajlperiode, Drucksache 18/12060. 05.07; Bundestag: Berlin, Germany, 2017.

60. Sternkopf, B.; Nowack, F. Lobbying: Zum Verhältnis von Wirtschaftsinteressen und Verkehrspolitik. In Handbuch Verkehrspolitik; Schwedes, O., Canzler, W., Knie, A., Eds.; Springer: Wiesbaden, Germany, 2016; pp. 381-399.

61. Lijphart, A. Patterns of Democracy: Government forms and Performance in Thirty-Six Countries, 2nd ed.; Yale University Press: New Haven, CT, USA, 2012. 
62. BMUB. Umweltbewusstsein in Deutschland 2016: Ergebnisse einer Repräsentativen Bevölkerungsumfrage; Bundesministerium für Umwelt, Naturschutz, Bau und Reaktorsicherheit: Berlin, Germany, 2017. Available online: https:/www.umweltbundesamt.de/sites/default/files/medien/1968/publikationen/ umweltbewusstsein_in_deutschland_2016_barrierefrei.pdf (accessed on 11 May 2017).

63. Burmeister, K. Umkämpfte Arbeit in der Automobil-Industrie. Das Beispiel Automotiv-Cluster in Baden-Württemberg. Prokla Z. Für Krit. Soz. 2019, 49, 277-294.

64. Walgrave, S.; van Aelst, P. The contingency of the mass media's political agenda setting power: Toward a preliminary theory. J. Commun. 2006, 56, 88-109. [CrossRef]

65. Von Schneidemesser, D.; Herberg, J.; Stasiak, D. Wissen auf die Straße. Kokreative Verkehrspolitik jenseits der "Knowledge-Action-Gap". In Das Wissen der Nachhaltigkeit. Herausforderungen zwischen Forschung und Beratung; Lüdtke, N., Henkel, A., Eds.; Oekom: Munich, Germany, 2018; pp. 107-128.

66. Paper Planes, E.V. Radbahn Berlin: Future Visions for the Ecomobile City; JOVIS Verlag: Berlin, Germany, 2018.

67. Widmann, R. Das Projekt Nordbahntrasse Wuppertal: Eine Bürgerinitiative Entwickelt und Baut Gemeinsam mit der Stadtverwaltung Einen Fuß- und Radweg. Praxisbericht im Nationaler Radverkehrsplan, Fahrradportal. Deutsches Institut für Urbanistik gGmbH. 2016. Available online: https://nationalerradverkehrsplan.de/de/praxis/eine-buergerinitiative-entwickelt-und-baut (accessed on 20 January 2020).

68. Beck, S. The challenges of building cosmopolitan climate expertise: The case of Germany. Wiley Interdiscip. Rev. Clim. Chang. 2012, 3,1-17. [CrossRef]

69. Hustedt, T. Analyzing policy advice. The case of climate policy in Germany. Cent. Eur. J. Public Policy 2013, 7, 88-110.

70. Brand, U. In der Wachstumsfalle. Die Gewerkschaften und der Klimawandel. Blätter für deutsche und international Politik 2019, 7, 79-88. Available online: https://www.blaetter.de/ausgabe/2019/juli/in-derwachstumsfalle (accessed on 2 April 2020).

71. Jungk, R. The Nuclear State; John Calder: London, UK, 1979.

72. Bossel, H.; Krause, F.; Müller-Reismann, K.-F. Energiewende: Wachstum und Wohlstand ohne Erdöl und Uran; S. Fischer: Frankfurt/Main, Germany, 1980.

73. Bosse, J. Zivilgesellschaftlicher Protest und seine Wirkung. Es liegt was in der Luft. Politische Ökologie 2019, 37, 31-36.

74. Oei, P.-Y.; Brauers, H.; Herpich, P.; Hirschhausen, C.; von Prahl, A.; Wehnert, T.; Bierwirth, A.; Fischedick, M.; Kurwan, J.; Mersmann, F.; et al. Phasing Out Coal in the German Energy Sector: Interdependencies, Challenges and Potential Solutions; Berlin, Deutsches Institut für Wirtschaftsforschung; Wuppertal Institut für Klima, Umwelt, Energie; Ecologic Institute: Berlin, Germany, 2019.

75. Öko-Institut. Die Deutsche Kohle-Verstromung bis 2030. Eine Modellgestützte Analyse der Empfehlungen der Kommission "Wachstum, Strukturwandel und Beschäftigung"; Öko-Institut: Berlin, Germany, 2019.

76. Sander, H. Ende Gelände: Anti-Kohle-Proteste in Deutschland. Forsch. Soz. Beweg. 2017, 30, 26-36. [CrossRef]

77. Engels, A.; Hüther, O.; Schäfer, M.; Held, H. Public climate-change skepticism, energy preferences and political participation. Glob. Environ. Chang. 2013, 23, 1018-1027. [CrossRef]

78. Scharpf, F.W. Demokratietheorie Zwischen Utopie und Anpassung; Universitätsverlag: Konstanz, Germany, 1970.

79. Trade Unions in the Green Economy. Working for the Environment; Rathzel, N., Uzzell, D., Eds.; Routledge: London, UK; New York, NY, USA, 2013.

80. Soder, M.; Niedermoser, K.; Theine, H. Beyond growth: New alliances for socio-ecological transformation in Austria. Globalizations 2018, 15, 520-535. [CrossRef]

81. Schmidt, V.A. Democracy and legitimacy in the European Union revisited: Input, output and 'throughput'. Political Stud. 2013, 61, 2-22. [CrossRef]

82. Humphreys, A.; Grayson, K. The intersecting roles of consumer and producer: A critical perspective on co-production, co-creation and prosumption. Sociol. Compass 2008, 2, 963-980. [CrossRef]

83. ILO (International Labour Organization). Resolution Concerning Sustainable Development, Decent Work and Green Jobs; ILO: Geneva, Switzerland, 2013.

(C) 2020 by the authors. Licensee MDPI, Basel, Switzerland. This article is an open access article distributed under the terms and conditions of the Creative Commons Attribution (CC BY) license (http://creativecommons.org/licenses/by/4.0/). 